\title{
Measuring Attitude of Rural Youth towards Dairying as an Occupation: A Likert Scale
}

\author{
Arindam $\mathrm{Nag}^{1 *}$, Sujeet Kumar Jha ${ }^{2}$, Asif Mohammad ${ }^{3}$ and Sanjit Maiti ${ }^{2}$ \\ ${ }^{1}$ Department of Extension Education, Dr. Kalam Agricultural College \\ (Bihar Agricultural University), Arrabari, Kishnganj, Bihar, India \\ ${ }^{2}$ Dairy Extension Division, ICAR-National Dairy Research Institute, Karnal, Haryana, India \\ ${ }^{3}$ ICAR-NDRI, Eastern Regional Station, Kalyani, West Bengal, India \\ *Corresponding author
}

\begin{tabular}{|c|c|}
\hline \multicolumn{2}{|r|}{ A B S T R A C T } \\
\hline & \multirow{5}{*}{$\begin{array}{l}\text { Dairying plays a vital role in small and marginal farming situation in India. However, the } \\
\text { flourish of dairy sector is not at same rate across the states. Various reasons have been } \\
\text { attributed for this, whatever the reasons may be; one prominent aspect is rural youth's } \\
\text { decision to choose dairying as occupation. So a study was conducted to understand the } \\
\text { attitude possessed by rural youth towards dairying as an occupation in Bihar and West } \\
\text { Bengal states of India. For this an instrument to measure attitude of rural youth towards } \\
\text { dairying as an occupation was developed by following likert method. The reliability and } \\
\text { validity of the developed scale was } 0.81 \text { and } 0.83 \text { respectively. The results showed that } \\
41.66 \text { per cent farm youth showed favourable attitude towards dairying as occupation } \\
\text { whereas } 61.67 \text { per cent of non-farm youth showed unfavourable attitude towards dairying } \\
\text { as occupation. The results indicated that attitude of non-farm youth was more negative } \\
\text { towards dairying, implying strong intervention is needed to make positive attitude towards } \\
\text { dairying among non-farm youth. }\end{array}$} \\
\hline & \\
\hline $\begin{array}{l}\text { Attitude, Dairying, } \\
\text { Rural youth, Likert } \\
\text { scale. }\end{array}$ & \\
\hline Article Info & \\
\hline $\begin{array}{l}\text { Accepted: } \\
23 \text { October } 2017 \\
\text { Available Online: } \\
10 \text { December } 2017\end{array}$ & \\
\hline
\end{tabular}

\section{Introduction}

There are two important ways of thinking on the issue of rural youth vis-a-vis farming: Farming as the saviour of rural youth, or rural youth as the saviour of farming. Whatever may be the situation, one thing is quite evident that rural youth and farming are interrelated with each other. According to the latest Census of India (2011), the total population of India is 1.21 billion and 66 per cent of population is up to 35 years of age. Even if 18 to 35 years of age category is considered, 36 per cent population would be covered in it. Demographical distribution of
India is very much skewed towards lower age. According to the latest survey of National Sample Survey Organization (2013), 64.1 per cent of rural people are engaged in the agricultural sector. In rural areas, especially among marginal and small farmers, dairying provides a supplementary income opportunity, and many a time, it may be only livelihood option for landless peasants. Livestock sector specifically dairying provides livelihood security. But migratory intention of rural youth towards urban area, had made the basic tenet of studying attitude 
of rural farm and non-farm youth towards dairying. As many psychological studies proved attitude could be important predictor for future behaviour, so the study was specifically designed to develop an effective instrument with the following objectives:

To develop a scale to measure attitude towards dairying as occupation among rural youth and to classify rural youth in different categories based on attitude towards dairying

\section{Materials and Methods}

In the present inquiry, an effort was made to systematically develop a scale to measure attitude of rural youth towards dairying as an occupation. Moreover, developed instrument was used for measuring attitude towards dairying as occupation and rural youth had been classified by taking cumulative square root frequency method.

\section{Locale of the study}

The study was conducted in Bihar and West Bengal which has largest number of marginal land holding, both, in terms of absolute number and percentage of total holding (Agricultural Statistics at a Glance, 2012). The study was conducted by taking two districts from each state based on percentage of rural population into the total population. By this criterion, districts of both the states were classified into two categories, viz., relatively high rural populated districts and relatively low rural populated districts by taking median value as the cutting point. So Coochbehar and Nadia district from West Bengal; and, Vaishali and Muzaffarpur from Bihar were selected. In total 8 blocks were selected for the study. Coochbehar-1 and Coochbehar-2 from Coochbehar district; Haringhata and khardah block from Nadia district of West Bengal. Similarly, Sakra and Katra blocks from Muzaffarpur district;
Mahua and Chehrakala blocks from Vaishali district of Bihar were randomly selected. From each block 30 rural youth were selected randomly among which 15 were farm youth and 15 were non-farm youth. Thus in total 240 rural youth of which 120 were rural farm youth and 120 were rural non-farm youth were personally interviewed for the study. Farm Youth happened to be a male, aged between 18 to 35 years, who was a resident of village at the time of interview and whose primary occupation was agriculture. Whereas, Non-farm Youth was a male, aged between 18 to 35 years, who was a resident of village at the time of interview and whose family was dependent on agriculture as a source of livelihood; albeit the respondent himself was not employed in agricultural sector. The term agriculture was broadly taken to incorporate crop farming and dairying.

\section{Stepwise procedure of attitude scale development}

Broadly seven step procedures were followed for the construction of scale. These were

Define construct

Identification and operationalization of different dimensions

Item collection, development and scrutiny of items

Item analysis by calculating $\mathrm{t}$ statistic

Reliability analysis

Validity testing

Step 1: Defining construct

Construct is concept adopted for specific scientific purpose. Here the construct was "Attitude towards dairying as an occupation". 
Theoretically attitude is defined as relative psychological position of a person towards a referent point. "Attitude towards dairying as an occupation" was operationally defined as the feelings associated with, and held by rural youth regarding dairying as an occupation. Here Dairying as an occupation means dairy farming as a livelihood activity.

\section{Step 2: Identification and operationalization of various dimensions}

The second step was to identify various dimensions of the construct and those dimensions was then clearly defined. This would have implications like act as guideline for developing items, helps experts to provide valid judgement etc. Various dimensions were identified through careful thinking and consulting experts of the field of Extension Education. Broadly five dimensions were identified. The operationalization of various dimension are given in Table 1.

\section{Step 3: Item collection, development and scrutiny}

Initially items were collected and developed from researcher's own experience, review of literature, consultation with experts etc.

Items were developed by keeping in mind the following criteria

Items should be in line with the Edward (1969) criteria for attitude statements.

Statements were selected to cover five dimensions, viz., attachment to dairying, Socio-economic aspects of dairying, Complexity of operation of dairying, Occupational prospects of dairying, Feeling towards knowledge of dairying.

Approximately equal numbers of positive and negative statements were formulated.
Each dimension broadly covered two aspect, viz., statements related to farming occupation as a whole and statements related to dairying in specific.

Then based on carefully scrutiny of items, reframe/ deletion of items were made.

\section{Step 4: Item analysis}

Carefully scrutinized items were sent to expert in questionnaire form. Two mode of sending were used, viz.

Electronic form (online form by using Google form) and

Printed form

Overall 24 experts returned the rated questionnaire and based on the rating provided by them, t-statistics was calculated.

\section{Procedure for item selection}

The selected items were preliminary administered to the expert for rating in five categories, namely strongly disagree, disagree, neutral, agree and strongly agree. For positive statements scoring was done from 1 to 5 for the continuum starting with strongly disagree to strongly agree; and reverse scoring was done for the negative statements.

On the basis of total score upper and lower $25 \%$ subjects were selected (as reference group).

Then calculation of $t$ value for each item was done

Items were selected based on higher t value over a cut-off point. $t$ value should be greater than or equal to 1.75 for final inclusion of items in the scale (Edward,1969). 
$t=\frac{\overline{X_{H}}-\overline{X_{L}}}{\sqrt{\frac{S_{H}^{2}}{n_{H}}+\frac{S_{L}^{2}}{n_{L}}}}$

Where,

$\overline{X_{H}} \quad=$ Mean score of a given statement for the high group

$X_{L} \quad=$ Mean score of a same statement for the low group

$S_{H}^{2} \quad=$ The variance of the distribution of responses of the high group to the statement

$S_{L}^{2} \quad=$ The variance of the distribution of responses of the low group to the statement

$n_{H} \quad=$ The number of subjects in the high group

$n_{L} \quad=$ The number of subjects to the low group

\section{Step 5: Reliability analysis}

Reliability can be estimated by three methods, these are test-retest methods, internal consistency methods and alternative forms. Previous researchers have categorically accepted that reliability is not measured but estimated; and the reliability is always of test scores and not of test itself (Pedhazur and Schmelkin, 1991; Caruso, 2000; Yin and Fan, 2000; Streiner, 2003). The basic form of measuring internal consistency is split half method. Internal consistency measure helps to assess homogeneity of items. Split halves method splits the entire item into two parts and finds the inter-correlation between the two. As this division can be done in no of ways, the correlation tends to vary. So to nullify this argument famous equation of Kuder and Richardson (1937) was advocated by various researchers. It used the average of all possible correlation among the halves. But major limitation of KR-20 (the famous twentieth formula of Kuder and Richardson) was applicability of only dichotomous response set. This was later solved by Cronbach (1951) by coefficient $\alpha$. For this study Cronbach $\alpha$ was adopted.

\section{Step 6: Validity testing}

For any measuring instrument validity is essential. Validity asks the very basic question, "are we measuring, what we are supposed to measure?" Thus a valid instrument is precursor of effective measurement. In the present context Content validity of the scale was ascertained to know whether the scale was really measuring the attitude of rural youth towards dairying as occupation. Various authors defined content validity in various worded form, but taking main component from those definition, Haynes et al., (1995) defined content validity as "the degree to which elements of an assessment instrument are relevant to and representative of the targeted construct for a particular assessment purpose."

The methodology of content validity can be divided into two phase, conceptualization of different domains of the construct (attitude towards dairying) for the development of items and then expert evaluation of the relevance of the scale's content (Lynn, 1986; Beck and Gable, 2001; Mastaglia, Toye, and Kristjanson, 2003; Polit and Beck, 2006). The list of items was provided to experts with ordinal scale with four possible responses. The responses include a rating of $1=$ not relevant, 2 = somewhat relevant, $3=$ quite relevant, and $4=$ very relevant. Researchers advocating the use of this approach specify that ratings of 1 and 2 are considered "content invalid," whereas ratings of 3 and 4 are considered to be "content valid" (Lynn, 1986; Waltz and Bausell, 1983). 
The score then used to calculate two indices by following Lynn (1986) for measuring content validity of the attitude towards dairying scale. These two indices were 1 . Content validity of individual items (I-CVI) and 2. Content validity of the overall scale (SCVI). Content validity of individual items (ICVI) was measured by the proportion of experts giving item a relevance rating 3 or 4 and validity of overall scale (S-CVI) was measured by the average of item content validity index of all the scale items. But there is another approach of calculating S-CVI through Universal agreement (UA) approach. S-CVI/ UA approach was not followed as it requires $100 \%$ agreement among judges over all the items of the scale, and no. of judges, practically the content validity would depress. So Average I-CVI was preferred over S-CVI/ UA. Lynn's (1986) and Polit and Beck (2006) suggested that for achieving excellent content validity of a scale, it would be composed of items with $\mathrm{I}-\mathrm{CVI}=1.00$ with 3 to 5 experts and a minimum I-CVI of 0.78 for 6 to 10 experts and for SCVI/ Ave of 0.90 or higher.

\section{Results and Discussion}

Initially after scrutiny 32 statements were retained and sent for judges rating; based on the judges score, mean score and $t$ value was calculated (Table 2). Then after eliminating items which had t-value greater than or equal to 1.75 only 20 items were retained. Then the scale was used to collect data for reliability analysis. The reliability analysis was done in Jalpaiguri district of West Bengal by taking 30 rural youth as sample. The results of split half method of reliability test showed that Cronbach's alpha was 0.78. However, as much as six items were showing enhancement of alpha value, when those statements were left. So presence of these statements tends to reduce the alpha value, which signifies that these six statements were not important to include in the scale (Table 3).

Table.1 Dimensions of attitude towards dairying as an occupation

\begin{tabular}{ll}
\hline \multicolumn{1}{c}{ Dimensions } & \multicolumn{1}{c}{ Operational definition } \\
\hline Attachment to dairying & $\begin{array}{l}\text { The degree to which a rural youth felt (either } \\
\text { positively or negatively) connection, bindings to } \\
\text { the farming occupation as a whole and dairying, } \\
\text { in particular. }\end{array}$ \\
The degree to which a rural youth felt (either \\
positively or negatively) about the socio- \\
economic impact of farming as a whole and \\
dairying, in particular. \\
The degree to which a rural youth felt (either \\
positively or negatively) about the difficulty of \\
operation of farming activity as a whole and \\
dairying, in particular. \\
The degree to which a rural youth felt (either \\
positively or negatively) about the future aspect \\
of farming as a whole and dairying, in particular. \\
The degree to which a rural youth felt (either \\
positively or negatively) about the possessed and \\
required knowledge/ understanding or both vis-a- \\
vis farming as a whole and dairying, in particular.
\end{tabular}


Table.2 Calculation of $\mathrm{t}$ value of statements for construction of attitude towards dairying scale

\begin{tabular}{|c|c|c|c|}
\hline Dimension & Statements & Mean Score & t value \\
\hline A. & 1. I feel comfortable in practising dairying. \# & 4.08 & 1.54 \\
\hline \multirow{7}{*}{$\begin{array}{l}\text { Attachment to } \\
\text { dairying }\end{array}$} & 2. I feel sorry of being a member of farm family. & 3.13 & 3.35 \\
\hline & 3. I do not like farmer's way of life.* & 3.09 & 15 \\
\hline & $\begin{array}{l}\text { 4. Father's engagement in dairying motivates me to } \\
\text { choose dairy farming.\# }\end{array}$ & 4.13 & 1.24 \\
\hline & $\begin{array}{l}\text { 5. If I get any office job, then I would not like to } \\
\text { engage myself in the farming.* }\end{array}$ & 2.50 & 5.07 \\
\hline & $\begin{array}{l}\text { 6. A young farmer can fulfil his desire through } \\
\text { farming. }\end{array}$ & 4.04 & 2.00 \\
\hline & 7. Farming is a monotonous occupation. & 3.33 & 3.38 \\
\hline & $\begin{array}{l}\text { 8. Advantages of dairying are more than its } \\
\text { disadvantages.* }\end{array}$ & 4.04 & 4.23 \\
\hline \multirow{8}{*}{$\begin{array}{l}\text { B. Socio- } \\
\text { economic } \\
\text { aspect of } \\
\text { dairying }\end{array}$} & 1. Farmers are well-respected in the society. & 3.17 & 1.75 \\
\hline & $\begin{array}{l}\text { 2. Farming is a noble occupation as they feed the } \\
\text { whole country.\# }\end{array}$ & 3.96 & 1.59 \\
\hline & $\begin{array}{l}\text { 3. Dairying could be a potentially a major employer } \\
\text { of rural youth. }\end{array}$ & 4.17 & 2.90 \\
\hline & $\begin{array}{l}\text { 4. Farming does not help in maintaining a proper } \\
\text { 'standard of living'. }\end{array}$ & 2.42 & 13.00 \\
\hline & 5. Marital prospects of farmers are relatively poor.\# & 2.58 & 1.73 \\
\hline & $\begin{array}{l}\text { 6. I would like to sell my farm produce to the } \\
\text { maximum extent rather than consuming it for only } \\
\text { home purposes.\# }\end{array}$ & 3.92 & 0.00 \\
\hline & $\begin{array}{l}\text { 7. 'Dairy farming' is not a profitable business for a } \\
\text { youth like me. }\end{array}$ & 2.75 & 2.24 \\
\hline & $\begin{array}{l}\text { 8. Farming tends to isolate a person from the } \\
\text { society.\# }\end{array}$ & 3.42 & -1.86 \\
\hline \multirow{5}{*}{$\begin{array}{l}\text { C. } \\
\text { Complexity } \\
\text { of operation } \\
\text { of dairying }\end{array}$} & $\begin{array}{l}\text { 1. A farmer bears great risk, in order to get little } \\
\text { success.\# }\end{array}$ & 2.54 & 1.27 \\
\hline & $\begin{array}{l}\text { 2. Chilling and Storage facility makes dairying a } \\
\text { troublesome occupation. }\end{array}$ & 2.46 & 5.07 \\
\hline & $\begin{array}{l}\text { 3. Processing of milk possess a great threat which } \\
\text { leads to distress selling.* }\end{array}$ & 2.38 & 4.92 \\
\hline & 4. I feel farming is drudgery prone. & 2.83 & 1.93 \\
\hline & $\begin{array}{l}\text { 5. I will be ready to operate in group mode for } \\
\text { improving dairy business. }\end{array}$ & 3.75 & 4.57 \\
\hline \multirow{4}{*}{$\begin{array}{l}\text { D. } \\
\text { Occupational } \\
\text { prospect of } \\
\text { dairying }\end{array}$} & 1. Farming provides opportunity to be independent.\# & 3.92 & 0.96 \\
\hline & $\begin{array}{l}\text { 2. I would leave dairying in future even if presently I } \\
\text { am associated with dairy.* }\end{array}$ & 2.54 & 4.00 \\
\hline & 3. My family would expect me to become a farmer.* & 2.92 & 6.71 \\
\hline & 4. A farmer can't be considered as an influential & 2.61 & 6.53 \\
\hline
\end{tabular}


person of the locality.

5. 'Dairy-based Farming System' is an option for 4.41

income-augmentation of the rural youth.\#

6. By living in farm, I would make my children's 2.52 future dull.\#

E. Feeling 1. My education level is more than to be a dairy 2.38 knowledge of farmer. dairying 2. My lack of knowledge about modern dairy
farming practices is one of the reasons for my apathy towards dairying.\#

3. I am ready to obtain information regarding 4.17 farming from anyone in any form.

4. I feel that I have ample knowledge about Dairy 2.63 farming techniques.\#

5. I will strive for undergoing training in dairying, 3.96 even if the cost of training is to be borne by me.

\# indicates items that were deleted, as possessing t-value less than 1.75.

* Indicates items that were discarded during reliability test, as incorporating those items tend to reduce Cronbach's alpha value

Table.3 Scale to measure attitude of rural youth towards dairying as occupation

\begin{tabular}{|c|c|c|c|c|}
\hline S1. No. & Statements & SA & A N DA & SDA \\
\hline 1. & Farmers are well-respected in the society. & & & \\
\hline 2. & I feel sorry of being a member of farm family. & & & \\
\hline 3. & $\begin{array}{l}\text { Dairying could be a potentially a major employer of rural } \\
\text { youth. }\end{array}$ & & & \\
\hline 4. & $\begin{array}{l}\text { Farming does not help in maintaining a proper 'standard } \\
\text { of living' }\end{array}$ & & & \\
\hline 5. & My education level is more than to be a dairy farmer. & & & \\
\hline 6. & $\begin{array}{l}\text { I am ready to obtain information regarding dairy farming } \\
\text { from anyone in any form. }\end{array}$ & & & \\
\hline 7. & $\begin{array}{l}\text { Chilling and Storage facility makes dairying a difficult } \\
\text { occupation. }\end{array}$ & & & \\
\hline 8. & $\begin{array}{l}\text { A farmer can't be considered as an influential person of } \\
\text { the locality. }\end{array}$ & & & \\
\hline 9. & A young farmer can fulfil his desire through farming. & & & \\
\hline 10. & Farming is a monotonous occupation. & & & \\
\hline 11. & $\begin{array}{l}\text { 'Dairy farming' is not a profitable business for a youth } \\
\text { like me }\end{array}$ & & & \\
\hline 12. & $\begin{array}{l}\text { I will strive for undergoing training in dairying, even if the } \\
\text { cost of training is to be borne by me }\end{array}$ & & & \\
\hline 13. & I feel farming is drudgery prone. & & & \\
\hline 14. & $\begin{array}{l}\text { I will be ready to operate in group mode for improving } \\
\text { dairy business. }\end{array}$ & & & \\
\hline
\end{tabular}

$\mathrm{SA}=$ Strongly Agree, $\mathrm{A}=$ Agree, $\mathrm{N}=$ Neutral, $\mathrm{D}=$ Disagree, SDA= Strongly Disagree 
Table.4 Distribution of rural youth based on attitude towards dairying

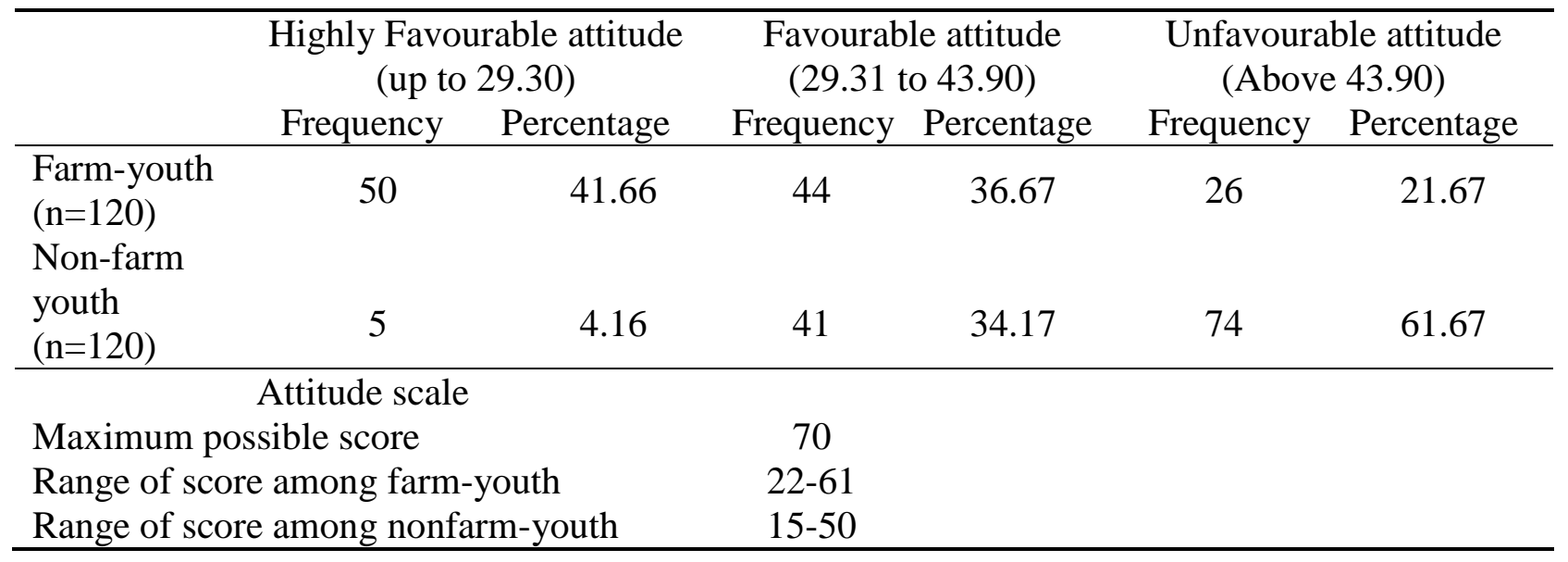

Then, by following same method, with the rest 14 statements, the improvement of Cronbach alpha value $(0.81)$ was found out. So the ultimate reliability of the scale was 0.81 . Moreover the validity of the scale was also calculated, by calculating content validity. The scale content validity index value was 0.81 . So the developed final scale contains 14 items and which could be administered among rural youth with five point continnum ranging from Strongly Agree (SA), Agree (A), Nutral (N), Disagree (D), to strongly Disagree (SD).

\section{Attitude of rural youth towards dairying}

The rural youth have been classified, in terms of attitude towards dairying, in three categories and presented in Table 4. The classification was done by following cumulative square root frequency method. Majority of farm youth 78.33 percent showed favourable to highly favourable attitude towards dairying, it may be because large number of farm youth were following dairying as occupation (in combination with other enterprise). Similar findings also reported by Patel and Chauhan (2009) during their study on entrepreneurial attitude of youth. Among non-farm youth 61.67 percent showed unfavourable attitude towards dairying and 38.33 percent showed favourable to highly favourable attitude towards dairying. The score of Attitude towards dairying as occupation among farm youth varies from 22 to 61 whereas for non-farm youth the same varies from 15-50. This indicates overall score of attitude scale was on the lower side in non-farm youth than farm youth.

At a time when rural youth were less attracted towards farming sector as a whole, the scale to measure attitude towards dairying can be helpful to classify rural youth based on attitude towards dairying. Thus it will help to target extension intervention to the identified category of youth. As attitude may predict behaviour, so attitude towards dairying could be a handy instrument to analyze and understand rural youth's behaviour as a dairy farmer. The scale showed unfavourable attitude towards dairying among the non-farm youth in the study locale, which should be taken care of by the concerned livestock department to change those attitudinal positions.

\section{Acknowledgement}

Authors are very thankful to Indian Council of Medical Research (ICMR) New Delhi for 
providing fellowship during the research work. We also extend our gratitude to the Director, ICAR-National Dairy Research Institute, Karnal, Haryana, India for support and encouragement.

\section{References}

Agricultural Statistics at a glance, 2012. Directorate of Economics and Statistics, Department of Agriculture and Cooperation, Ministry of Agriculture, Government of India. 320.

Beck, C. T., and Gable, R. K. 2001. Ensuring content validity: An illustration of the process. Journal of Nursing Measurement. 9: 201-215.

Caruso, J. C., 2000. Reliability generalization of the NEO personality scales. Educational Psychological Measurement. 60: 236-254.

Census of India, 2011. New Delhi: Registrar General of India.

Cronbach, L. J., 1951. Coefficient alpha and the internal structure of tests. Psychometrika. 16 (3): 297-334.

Edward A. L., 1969. Techniques of attitude scale construction. Vakils, Feffer and Simons Private LTD., New York.

Haynes, S. N., Richard, D. C. S. and Kubany, E. S. 1995. Content validity in psychological assessment: A functional approach to concepts and methods. Psychological Assessment. 7(3): 238-247.

Kuder, G. F., and Richardson, M. W. 1937. The theory of the estimation of test reliability. Psychometrika. 2 (3): 151-160.

Likert, R., 1932. A Technique for the Measurement of Attitudes. Archives of Psychology. 140: 1-55.
Lynn, M. R., 1986. Determination and quantification of content validity. Nursing Research. 35: 382-385.

Mastaglia, B., Toye, C. and Kristjanson, L. J. 2003. Ensuring content validity in instrument development: Challenges and innovative approaches. Contemporary Nurse. 14: 281-291.

National Sample Survey Organisation, 2013. Key indicators of employment and unemployment in India 2011-2012. NSS $68^{\text {th }}$ Round (July 2011 - June 2012).

Patel, M. C. and Chauhan, N. B. 2009. Entrepreneurial Attitude of Youth. Agriculture Science Digest. 29 (3): 212214.

Pedhazur, E. J., and Schmelkin, L. P. 1991. Measurement, design and analysis: An integrated approach. Hillsdale, NJ: Lawrence Erlbaum Associates, Inc.

Polit, D. F., and Beck, C. T. 2006. The Content Validity Index: Are You Sure You Know What's Being Reported? Critique and Recommendations. Research in Nursing \& Health. 29: 489-497.

Streiner, D. L., 2003. Starting at the beginning: An introduction to coefficient alpha and internal consistency. Journal of Personality Assessment. 80(1): 99-103.

Waltz, C., and Bausell, R. B. 1983. Nursing research: Design, statistics, and computer analysis. Philadelphia: F. A. Davis.

Yin, P., and Fan, X. 2000. Assessing the reliability of Beck Depression Inventory Scores: Reliability generalization across studies. Educational and Psychological Measurement. 60: 201-223.

\section{How to cite this article:}

Arindam Nag, Sujeet Kumar Jha, Asif Mohammad and Sanjit Maiti. 2017. Measuring Attitude of Rural Youth towards Dairying as an Occupation: A Likert Scale. Int.J.Curr.Microbiol.App.Sci. 6(12): 3173-3181. doi: https://doi.org/10.20546/ijcmas.2017.612.371 